\title{
UPAYA PENANGANAN KREDIT MODAL KERJA DI PT. BANK PERKREDITAN RAKYAT (BPR) LENGAYANG
}

\author{
Dini Sulastri Idris, Ratna Widayati \\ Akademi Keuangan Dan Perbankan"Pembangunan" Padang \\ dini.idris17@gmail.com \\ ratnawidayati@akbpstie.ac.id
}

\begin{abstract}
Based on the results of research on the previous chapter can be summed up efforts in handling bad debt in the PT. BPR Lengayang.The cause of the bad debt in PT. BPR Lengayang in akibatkan.byweakening the economic activities of the community, the issue of the operational efforts, this is very more influenced on the debtor's credit, and smoothness that have a less good fiith who intentionally delay payment at maturity. Handling the troubled creditbank is a party which is donewith the approach to the debtor via phone/sms or AO credits came home with spaciousness/debtor talk in a family, but to send a warning letter. The last step will be done is with a foreclosure guarantee.
\end{abstract}

Keyword:Bank, Kredit Bermasalah

PENDAHULUAN

Bank merupakan lembaga keuangan yang berfungsi sebagai financial intermediary atau perantara keuangan dari kedua pihak yang kelebihan dana dan pihak yang kekurangan dana.

Bank menurut pasal 1 ayat (2) undang-undang No.10 Tahun 1998 tentang perbankan, adalah badan usaha yang menghimpun dana dari masyarakat dalam bentuk simpanan dan menyalurkannya kepada masyarakat dalam bentuk kredit atau bentuk lainya dalam rangka meningkatkan taraf hidup masyarakat. Dalam perkembangan perekonomian bank sangat berperan penting dalam memenuhi kebutuhan perekonomian masayarakat menegah kebawah, dimana bank merupakan lembaga keuangan yang bertugas menghimpun dana dari masyarakat dan menyalurkan kembali kepada masyarakat dalam bentuk kredit untuk memenuhi kebutuhan dana kegiatan usaha.

Menurut Undang-undang No.10 tahun 1998 pasal 13 tentang perbankan lembaga Bank Perkreditan Rakyat (BPR) merupakan salah satu jenis bank Ruang lingkup operasional BPR lebih terbatas bila dibandingkan dengan ruang lingkup yang ada pada Bank Umum. Baik dari segi produk maupun pemodalan, perbedaan BPR dengan Bank Umum dari segi pendapatan operasi, dimana selain pendapatan bunga, pada bank umum 
cenderung lebih besar perannya terhadap profitabilitas seperti pendapatan dari jasa-jasa bank (melalui giro, dari transaksi yang terjadi di pasar uang, jual beli valas, transaksi L/C), sementara BPR dengan batasan-batasan usaha yang diperkenankan oleh otoritas perbankan, akibatnya sumber pendapatan operasional dari BPR tertumpu pada selisih antara pendapatan bunga kredit dengan biaya pendanaan.(Afriyeni, 2017) Kredit berasal dari bahasa Yunani, credere, yang berarti kepercayaan.Dengan demikian istilah kredit memiliki arti khusus, yaitu meminjamkan uang (penundaan pembayaran).

Menurut Undang-undang No. 10 tahun 1998 pasal 21 ayat 11. Kredit adalah penyediaan uang atau tagihan yang dapat dipersamakan dengan itu, berdasarkan persetujuan atau kesepakatan pinjam meminjam antara bank dengan pihak yang lain yang mewajibkan pihak pinjaman untuk melunasi utangnya setelah jangka waktu tertentu dengan pemberian bunga.

Kredit bermasalah adalah keadaan dimana nasabah sudah tidak sanggup membayar sebagian atau seluruh kewajiban kepada bank seperti yang telah diperjanjikannya. Kredit bermasalah menurut ketentuan Bank Indonesia merupakan kredit yang digolongkan ke dalam kolektibilitas Kurang Lancar (KL), Diragukan (D), dan Macet (M).(Lihani, Ngadiman, \& Hamidi, 2013)

Pemberian kredit dilakukan untuk meningkatkan taraf hidup masyarakat melalui pinjaman dana atau pemberian investasi berupa uang atau barang yang dapat digunakan dan kemudian dikembalikan dalam jangka waktu yang telah di tentukan sesuai perjanjian pada awal pemberian kredit.(Marlius, n.d.)

Bank PT. BPR Lengayang merupakan salah satu bank yang sangat berperan penting dalam pertumbuhan ekonomi di kalangan masyarakat menengah kebawah, penyaluran modal kepada masyarakat berupa kredit yang bertujuan untuk mendukung kegiatan perekonomian di daerah lengayang.

Kredit dapat membantu masyarakat dalam memenuhi kebutuhan hidup, hal ini tak terkecuali untuk keperluan bisnis. Kredit bukan hanya mampu menggerakkan usaha para pembisnis besar namun juga termasuk wirausaha kecil dan pembisnis pemula.

Penyaluran Kredit oleh bank mengandung resiko yaitu kemungkinan penerima kredit tidak mampu melunasi kredit pada tepat waktu bahkan gagal bayar sama sekali, karena adanya keterbatasan kemampuan manusia dalam memprediksikan masa yang akan datang, oleh sebab itu bank harus merencanakan sedemikian rupa untuk menekan munculnya resiko kredit bermasalah. Berdasarkan uraian diatas maka penulis tertarik menuangkan dalam penelitian yang berjudul "Upaya Penanganan Kredit Modal Kerja Bermasalah di PT. BPR Lengayang"

Berdasarkan latar belakang di atas, maka rumusan masalah yang diangkat yaitu "Bagaimana Upaya Penanganan Kredit Modal Kerja Bermasalah di PT.BPR lengayang.

\section{METODE PENELITIAN}

Dalam menganalisa data, penulis mengunakkan analisis data kuantitatif sebagai metode penelitian yang menjelaskan secara descriptif mengenai bagaimana upaya penangganan kredit modal kerja yang bermasalah 
di PT. BPR Lengayang.

\section{HASIL DAN PEMBAHASAN}

\section{Prosedur Pemberian Kredit}

Prosedur pemberian kredit pada PT. Bank Perkreditan Rakyat Lengayang, dalam hal ini penulis ingin membatasi kredit modal kerja adalah sebagai berikut :

a. Permohonan Kredit

Pengajuan pemohonan kredit dilakukan secara tertulis dengan mengisi formulir yang telah disediakan dan melengkapi dokumen identitas sebagai berikut:

1. Foto copy KTP, SIM atau Paspor

2. Foto copy akta nikah (bagi yang sudah menikah)

3. Foto copy kartu keluarga

4. Foto copy buku tabungan apabila tidak memiliki nasabah wajib membuat buku tabungan baru.

5. Surat keterangan kerja/ SIUP/TDP/NPWP

6. Surat keterangan gaji (jika ada)

7. Surat bukti kepemilikan jaminan (BPKB/Sertifikat/Akta Deposito/surat kuasapenyerahan jaminan)

b. Penilaian dan analisis pemberian kredit

Setelah kelengkapan surat pemohonan kredit modal kerja yang dipenuhi nasabah, maka PT. BPR Lengayang akan melakukan analisis sebagai berikut:

\section{Character}

AO kredit terlebih dahulu melakukan wawancara kepada calon debitur, hal ini dilakukan untuk melihat karakter dari calon debitur.

2. Capacity

AO kredit melihat kemampuan calon debitur untuk melunasi kewajibannya, dengan cara melihat dari usaha yang dikelola/dimiliki calon debitur dan juga dilihat dari pendidikan dan wawasannya,

3. Capital

Penilaian dilakukan dengan cara melihat modal awal calon debitur, bank melihat dari rekening tabungan atau aset yang dimiliki calon debitur.

4. Condition Of Economy

AO kredit juga melakukan penilaian terhadap prospek bidang usaha calon debitur, dilihat dari peluang/prospek usaha yang dijalankan oleh nasabah.

5. Colleteral

AO kredit menilai jaminan yang diajukan calon debitur, apakah jaminan tersebut cukup sebagai jaminan untuk jumlah kredit yang diajukan.

c. Keputusan kredit

Setelah menganalisis maka PT. BPR Lengayang mengirim SPPK (surat pemberitahuan persetujuan kredit) kepada calon debitur dengan mencantumkan jumlah, jangka waktu kredit, suku bunga kredit serta jumlah angsuran, biaya administrasi, dan provisi dan komisi kredit. Apabila 
persetujuan kredit yang dipersyaratkan belum lengkap, maka pencairan ditangguhkan terlebih dahulu sampai persyaratan terpenuhi. Kredit yang disetujui AO kredit akan memanggil debitur untuk menandatangani akad perjanjian kredit (APK) dengan membawa dokumen asli kredit.

d. Perjanjian kredit

Setelah keputusan kredit disepakati maka bank dan nasabah melakukan akad perjanjian kredit sesuai dengan ketentuan PT. BPR Lengayang yaitu akad Perjanjian kredit ditandatangani oleh pihak bank sesuai dengan ketentuan intern bank dan debitur, pengikatan jaminan dan surat kuasa hak jual. Apabila debitur tidak mampu menyelesaikan kewajibannya, maka bank berhak menyita/menjual jaminan tersebut.

e. Pencairan kredit

Setelah perjanjian kredit disepakati maka pencairan akan dilakukan sebagai berikut :

1. Debitur dapat membuka rekening tabungan.

2. Debitur membuat surat kuasa untuk melakukan pendebetan rekening tabungan.

3. Bagian administrasi kredit membuat memo pencairan kepada bagian tabungan, beserta kwitansi pencairan kredit rangkap 2 nota kredit atas pencairan nota debet untuk pembebanan biaya administrsi, provisi dan komisi, notaris dan asuransi.

4. Debitur mentandatangani kwitansi pencairan kredit dihadapan petugas tabungan.

f. Pengawasan dan pembinaan kredit

PT. BRP Lengayang melakukan pengawasan kredit dan pembinaan terhadap debitur meliputi semua aspek perkreditan yaitu :

1. Meliputi kebenaran laporan tujuan penggunaan fasilitas kredit yang disampaikan oleh debitur secara berkala.

2. Memantau perkembangan kegiatan usaha debitur termasuk pemantauan melalui kegiatan kunjungan kepada debitur dan memberikan peringatan secara dini mengenai penurunan kualitas kredit yang diperkirakan mengandung resiko bagi bank.

3. Membuat laporan hasil kunjungan dan pembinaan terhadap usaha debitur.

4. Meneliti apakah pelunasan angsuran pokok dan bunga debitur sesuai dengan jadwal yang disepakati.

5. Memberikan peringatan kepada debitur yang menunggak angsuran pokok maupun bunga.

6. Memberikan pinalti/denda kepada debitur yang menunggak sesuai dengan ketentuan intern bank.

7. Memberikan surat pembinaan kepala debitur.

8. Mengambil langkah-langkah penyelamatan kredit.

\section{Kredit Bermasalah}

Kredit bermasalah mengambarkan terjadinya kegagalan dalam menangani resiko yang biasanya cenderung terjadi dan menyebabkan kerugian yang dialami oleh bank. Jika hal ini tidak dapat teratasi dengan baik maka akan mengakibatkan terjadi ketidak seimbangan terhadap bank.Kredit 
yang bermasalah di PT. BPRLengayang dibagi didasarkan kategori sebagai berikut :

1) Kredit dalam perhatian khusus yaitu kredit yang terdapat tunggakan pembayaran pokok ataupun bunga yang melampaui 90 hari dari waktu yang di sepakati.

2) Kredit kurang lancar yaitu kredit yang terdapat tunggakan pembayaran pokok ataupun bunga melampaui 120 hari dari waktu yang telah di sepakati.

3) Diragukan yaitu kredit yang terdapat tunggakan pembayaran pinjaman baik pokok dan atau bunga melampaui 180 hari yang telah di sepakati.

4) Kredit macet yaitu kredit yang terdapat tunggakan pembayaran pokok ataupun bunga di atas 180 hari dari waktu yang telah di sepakati.

Gambaran tentang kredit di PT. BPR Lengayang dapat dilihat dari tabel berikut :

Tabel 1

Jumlah keseluruhan kredit bermasalah dari tahun 2016-2018

(Dalam Bentuk Rupiah)

\begin{tabular}{|c|c|c|c|}
\hline Tahun & $\begin{array}{c}\text { Kredit Yang Di } \\
\text { Cairkan }\end{array}$ & $\begin{array}{c}\text { Kredit Yang } \\
\text { Beramasalah }\end{array}$ & $\begin{array}{c}\text { Presentase Kredit } \\
\text { Bermasalah }\end{array}$ \\
\hline 2016 & Rp. 28.451.020.000 & Rp. 646.413.000 & 22,7\% \\
\hline 2017 & Rp. 31.748.298.0s00 & Rp. 791.346.979 & $\mathbf{2 4 , 9 \%}$ \\
\hline 2018 & Rp. 35.986.894.000 & Rp. 827.132.611 & $\mathbf{2 2 , 9 \%}$ \\
\hline
\end{tabular}

Sumber : Laporan PT. BPR Lengayang

Jumlah data kredit yang bermasalah diatas semua sudah mencangkup keseluruhan jumlah kredit yang ada di PT. BPR Lengayang yang dikategorikan dalam perhatian khusus, kredit kurang lancar, diragukan, dan kredit macet.

Pada tahun 2017 terjadi peningkatan kredit bermasalah sebanyak $2,2 \%$ yang disebabkan oleh faktor eksternal seperti adanya penurunan kegiatan ekonomi masyarakat(debitur), masalah operasional usaha yang kurang lancar, dan debitur mempunyai itikad yang kurang baik, bahwa sebagian kredit macet yang terjadi di sebabkan oleh debitur yang sengaja menunda pembayaran angsuran pada saat jatuh tempo,(debitur cidera janji). Sedangkan pada tahun 2018 terjadi penurunan kredit bermasalah sebanyak $2 \%$, karena adanya pembenahan yang dilakukan bank, dan lebih selektif dalam memberikan pinjaman kepada calon debitur dan juga menurunkan tingkat suku bunga kredit.

Upaya Penanganan Kredit Bermasalah

Upaya yang dilakukan PT. BPR Lengayang dalam menanggani kredit bermasalah yang dilakukan adalah sebagai berikut :

a. Debitur dengan kategori kredit dalam perhatian khusus, dilakukan Dengan pendekatan kepada debitur melalui telepon ata sms atau AO kredit sendiri datang kelapangan/rumah debitur dengan membicarakan secara kekeluargaan atau lebih bersifat persuatif.

b. Debitur dalam kategori kurang lancar, bank akan Mengirim surat peringatan (SP I) (penagihan secara tertulis)

c. Debitur dalam kategori diragukan, akan melakukan beberapa langkah, 
yaitu dengan Reschuduling (perpanjangan jangka waktu kredit), Rescontioning (perubahan tingkat suku bunga atau denda). Dan penundaan pembayaran kewajiban bunga/pinalty atau penguranggan tunggakan pokok kredit.

d. Debitur dalam kategori kredit macet, bank mengirimkan surat peringatan (SP II) kembali kepada debitur. Jika tidak dihiraukan maka bank akan mengirimkan surat peringatan (SP III).

e. Apabila Debitur tidak menanggapinya maka bank akan melakukan penarikan agunan/jaminan dan akan dilelang sebagian atau seluruh agunan yang diajukan debitur pada saat pengajuan kredit.

\section{KESIMPULAN}

Berdasarkan hasil penelitian pada bab sebelumnya dapat disimpulkan upaya dalam penanganan kredit bermasalah di PT. BPR Lengayang.

1. Penyebab kredit bermasalah pada PT. BPR Lengayang di akibatkan, menurunnya kegiatan ekonomi masayarakat, masalah operasional usaha, hal ini sangat berpangaruh pada kelancaran kredit, dan debitur yang mempunyai itikad yang kurang baik yang sengaja menunda pembayaran pada saat jatuh tempo.

2. Penangganan kredit bermasalah yang dilakukan pihak bank adalahdengan melakukan pendekatan kepada debitur melalui telepone/sms atau AO kredit datang kelapangan/rumah debitur dengan membicarakan secara kekeluargaan, adapun dengan mengirim surat peringatan. Langkah terakhir yang akan dilakukan adalah dengan penyitaan jaminan.

\section{UCAPAN TERIMA KASIH}

Penulis mengucapkan terima kasih kepada pihak-pihak yang telah membantu dan mendukung penulis dalam mengerjakan tugas akhir ini di PT. BPR Lengayang serta dosen pembimbing Akademi Keuangan Perbankan dan Pembangunan, yang telah memberi dukungan penuh sehingga terlaksananya penelitian ini.

\section{DAFTAR PUSTAKA}

Afriyeni, A. (2017). Profitabilitas Bank Perkreditan Rakyat Di Kota Padang Di Tinjau Dari Rasio Likuiditas. Jurnal Benefita, 2(1), 22-32. https://doi.org/10.22216/jbe.v2i1.2104

Ambarsita, L. (2013). Analisis Penanganan Kredit Macet. Manajemen Bisnis, $3(01), 15-20$.

Alanshari, F., \& Marlius, D. (2018). Prosedur Pemberian Kredit KPR Pada PT. Bank Tabungan Negara (Persero) TBK Cabang Pembantu Bukittinggi. https://doi.org/10.31227/osf.io/rsfhc 
Amelia, L., \& Marlius, D. (2018). Pengendalian Kredit Dalam Upaya Menciptakan Bank Yang Sehat Pada PT. Bank Pembangunan Daerah Sumatera Barat Cabang Utama Padang. https://doi.org/10.31227/osf.io/kpc64

Barus, A. C., \& Lu, M. (2013). Pengaruh Spread Tingkat Suku Bunga Dan Rasio Pada Bank Umum Di Indonesia. Jurnal Wira Ekonomi Mikroskil, 3(April), 11-20. https://doi.org/10.1017/CBO9781107415324.004

Darmawanto, \& Fernos, J. (2019). Prosedur Pemberian Kredit Pada Bank Nagari Cabang Sijunjung. https://doi.org/10.31227/osf.io/psqfy

Darussalam, O. (2013). Faktor-Faktor Penyebab Kredit Bermasalah di PT.Bank Sulut Cabang Utama Manado. Jurnal EMBA, 1(4), 69-77.

Firdaus, R. N. (2015). Pengaruh Faktor Internal Dan Eksternal Yang Mempengaruhi Pembiayaan Bermasalah Pada Bank Umum Syariah Di Indonesia. $\quad$ El-Dinar, 3(1), 82-108. https://doi.org/10.1097/OPX.0b013e318181a91f.

Fitria, N., \& Linda Sari, R. (2017). Analisis Kebijakan Pemberian Dan Pengaruh Non Perfoming Loan Terhadap Loan To Deposito Ratio Pada PT. Bank Rakyat Indonesia (Persero), TBK Cabang Rantau, Aceh Tamiang.Disease Notes (Vol. 101). https://doi.org/10.1094/PDIS-08-16-1092-PDN

Lihani, R., Ngadiman, \& Hamidi, N. (2013). Analisis Manajemen Kredit guna Meminimalkan Risiko Kredit (Studi pada PD BPR BKK Tasikmadu Karanganyar), 1(3), 1-11.

Orlando, A., \& Susanto, R. (2019). Mekanisme Pencairan Kredit Usaha Rakyat Pada PT. Bank Rakyat Indonesia Unit Lubuk Buaya. https://doi.org/10.31219/osf.io/zuv2y

Pratama, D., \& Fernos, J. (2019). Prosedur Pelaksanaan Kredit Usaha Rakyat (KUR) Pada PT. Bank Nagari Cabang Padang. https://doi.org/10.31227/osf.io/ag68j

Pratiwi, Y. W. (2016). Analisis Manajemen Risiko Untuk Menimalisir Kredit Modal Kerja Bermasalah ( Studi pada PT Bank Rakyat Indonesia ( Persero ) Tbk . Cabang Jombang ). Jurnal Administrasi Bisnis (JAB), 32(1), 121-127.

Wahyu, T. A. (2017). Sistem Pendukung Keputusan Pemberian Kredit Usaha Kecil Menengah Pada BPR Prima Kredit Mandiri Dengan Menggunakan Metode Logika Fuzzy MADM Dan Fuzzy Sugeno, O(September), 1-15. https://doi.org/10.1017/CBO9781107415324.004 
Widayati, R. (2019). Aktivitas Pemberian Kredit Komersil Pada Bank Nagari Cabang Sijunjung. https://doi.org/10.17605/OSF.IO/QTVZ9

Widayati, R. (2019). Pelaksanaan Kredit Pada Bank Perkreditan Rakyat LPN Pasar Baru Durian Sawahlunto. https://doi.org/10.17605/OSF.IO/5HPAB

Widayati, R. (2019). Aktivitas Pemberian Kredit Usaha Pada PT. Bank Perkreditan Rakyat Batang Kapas. https://doi.org/10.17605/OSF.IO/EDPN4

Yoga, G. A. D. M., \& Yuliarmi, N. N. (2011). Faktor-Faktor yang Mempengaruhi Penyaluran Kredit BPR di Provinsi Bali. E-Jurnal Manajemen Universitas Udayana, 2(6), 284-293. 